\title{
PERHITUNGAN SEL BAHAN BAKAR REAKTOR PWR DENGAN PROGRAM WIMSD-5B
}

\author{
Santo Paulus Rajagukguk ${ }^{1)}$, S. Bakhri ${ }^{2)}$ dan T. Surbakti ${ }^{2)}$ \\ ${ }^{1)}$ Mahasiswa UNIMED FMIPA Jurusan Fisika, Medan, 20221 \\ ${ }^{2)}$ Pusat Teknologi dan Keselamatan Reaktor Nuklir-BATAN \\ Kawasan Puspiptek Gd 80 Tangsel, Banten, 15310
}

\begin{abstract}
ABSTRAK
PERHITUNGAN SEL BAHAN BAKAR REAKTOR PWR DENGAN PROGRAM WIMSD-5B. Perhitungan sel bahan bakar teras reaktor PWR telah dilakukan dengan menggunakan program komputer WIMSD-5B. Perhitungan dilakukan untuk mengetahui karakteristik neutronik bahan bakar teras reaktor PWR dengan variasi daya. Karakteristik neutronik diketahui dengan memperoleh konstanta makroskopik seperti k-inf, koefisien difusi, tampang lintang serapan dan fisi. Untuk itu dilakukan generasi sel bahan bakar dengan 69 grup energi neutron pada program transport satu dimensi (WIMSD-5B) menggunakan ENDF-BVII.1 data file. Bahan bakar dimodelkan sebagai sel satuan model cluster dengan susunan square pitch, kemudian dihitung dimensi satuan selnya. Satu satuan sel terdiri dari satu satuan bahan bakar dan moderator. Dari satu satuan sel ekivalen tersebut diperoleh data dimensi sel sebagai data masukan program WIMSD-5B yang dikenal dengan annulus. Hasil perhitungan faktor multiplikasi tak terhingga sel teras PWR yang dihitung dengan menggunakan paket program WIMSD-5B adalah 1,302338. Dari hasil perhitungan dapat dinyatakan bahwa nilai faktor multiplikasi tak terhingga, konstanta difusi, tampang lintang serapan, nu-fisi dan fluks neutron sangat dipengaruhi oleh fraksi bakar.
\end{abstract}

Kata kunci: bahan bakar, teras PWR, WIMSD-5B, energi neutron, konstanta makroskopik

\section{ABSTRACT}

CALCULATION OF PWR REACTOR FUEL CELLS WITH WIMSD-5B CODE. Calculation of core fuel cell PWR reactor has been done using the WIMSD-5B computer program. Calculations are performed to determine the neutronic characteristics of $P W R$ reactor core fuels with power variations. Neutronic characteristics are known by obtaining macroscopic constants such as k-inf, diffusion coefficient, cross section absorption and fission. Therefore, a fuel cell generation was carried out with 69 neutron energy groups in a one-dimensional transport program (WIMSD-5B) using ENDF-BVII.1 data file. The fuel is modeled as unit cells of cluster models with square pitch arrangement, to calculate the unit cell dimensions. One unit of cell consists of one unit of fuel and a moderator. From one equivalent cell unit, cell dimension data is obtained as input data for the WIMSD-5B program known as annulus. The calculation result of the infinite multiplication factor of PWR core cells using the WIMSD-5B is 1.302338. From the results, it can be stated that the value of the infinite multiplication factor, diffusion constanta, absorption cross section, nu-fission and neutron flux are strongly influenced by the fuel burn-up.

Keywords: fuel, PWR core, WIMSD-5B code, neutron energy, macroscopic constanta 


\section{PENDAHULUAN}

Salah satu program utama BATAN adalah melakukan kajian tentang PLTN (Pembangkit Listrik Tenaga Nuklir) tipe PWR (Pressurized Water Reactor) [1]. Untuk mendukung RENSTRA-BATAN tentang kajian teknologi dan keselamatan PLTN maka dilakukan penelitian tentang analisis sel bahan bakar PLTN dan yang dipilih adalah PLTN jenis PWR. Penelitian tentang teknologi dan keselamatan reaktor PWR dari sisi teknik perancangan (design) untuk PLTN perlu dilakukan. Perancangan suatu reaktor nuklir pada umumnya dimulai dari perhitungan sel material teras termasuk bahan bakarnya [2]. Berdasarkan konsep tersebut, pada penelitian ini dilakukan evaluasi parameter kisi sel teras PWR daya 1000 MW berbahan bakar $\mathrm{UO}_{2}$ [3]. Perhitungan parameter sel teras PWR dilakukan dengan menggunakan program transport neutron satu dimensi dengan 69 kelompok energi neutron yaitu WIMSD-5B $[4,5]$. Paket program WIMSD-5B dapat menghitung parameter kisi sel teras reaktor PWR dengan satu bahan bakar (pin cell) maupun dengan seperangkat bahan bakar. Sel diperhitungkan untuk $1 / 4$ perangkat elemen bakar dengan model cluster dengan susunan square pitch. Parameter sel atau pembangkitan konstanta kelompok dimaksudkan untuk mendapatkan harga rerata konstanta kelompok dalam suatu sel dengan cara menghomogenkan sel tersebut. Untuk memperoleh harga-harga konstanta kelompok yang bersesuaian dengan kondisi teras maka dicari nilai buckling aksial teras. Nilai buckling aksial ini ditentukan dengan memasukkan harga $\mathrm{K}_{\mathrm{eff}}$ teras dari data-data pemasok. Perhitungan konstanta kelompok dilakukan untuk material-material penyusun teras pada kondisi seperti di atas. Parameter sel atau konstanta tampang lintang sebagai keluaran program WIMSD-5B selanjutnya dapat digunakan sebagai masukan pada program difusi neutron untuk perhitungan teras seperti perhitungan kritikalitas dan parameter neutronik dan kinetik. Parameter sel merupakan masukan yang sangat menentukan keakuratan analisis pada perhitungan teras sehingga perhitungan parameter sel harus dihitung dengan teliti dan akurat. Mengingat pentingnya perhitungan sel teras PWR berbahan bakar $\mathrm{UO}_{2}$ ini maka perlu dilakukan perhitungan yang akurat menggunakan WIMSD-5B dengan nuklir data file ENDFB-VII.1[6].

\section{DISKRIPSI TERAS PWR}

Reaktor daya PWR yang dianalisis adalah reaktor daya jenis air tekan (Pressurized Water Reactor) yang didesain oleh Westinghouse [7]. Reaktor PWR tersebut memiliki konfigurasi teras seperti yang ditunjukan pada Gambar 1. Teras PWR pada awal siklus (BOC) disusun atas 3 
jenis pengkayaan yaitu 2,5\%, 3,0 \% dan 3,7 $\%$ masing-masing sebanyak 49 buah, 48 buah, 48 buah [8]. Jumlah perangkat bahan bakar yang menyusun teras reaktor PWR adalah 145 buah. Dimensi teras aktif PWR, perangkat bahan bakar dan reflektor dirangkum dalam Tabel 1. Reaktor PWR mempunyai bahan bakar jenis pelet selinderis dengan bahan bakar $\mathrm{UO}_{2}$ dan kelongsongnya Zircalloy-4 [9]. Di dalam kelongsong bahan bakar baik di bagian atas maupun bagian bawah terdapat ruang yang dimanfaatkan untuk menampung gas-gas hasil produk fisi. Setiap perangkat bahan bakar berisi 269 (17 x 17) elemen yang terdiri dari 264 buah elemen bakar dan 24 buah elemen guide thimble dan satu instrumentation tube. Bahan bakar juga dilengkapi perangkat kendali yang jumlahnya 24 buah pada satu perangkat bahan bakar yang sering disebut RCCA (rod cluster control assemblies). Material utama dari pembentuk elemen kendali adalah AgIn-Cd, sedangkan kelongsongnya adalah material Zirkaloy. Perangkat elemen kendali RCCA digunakan untuk mengontrol perubahan reaktivitas dan distribusi daya aksial. Selain RCCA ada juga perangkat elemen kendali GRCA (gray rod cluster assemblies) pada teras reaktor PWR yang digunakan untuk mengatur reaktivitas teras sesuai dengan perubahan beban. Air ringan digunakan sebagai pendingin dan moderator yang dicampur dengan boron cair yang berfungsi sebagai penyerap neutron [10]. Konsentrasi boron cair bervariasi jumlahnya sesuai dengan perubahan reaktivitas yang berubah karena perubahan fraksi bakar di dalam teras.

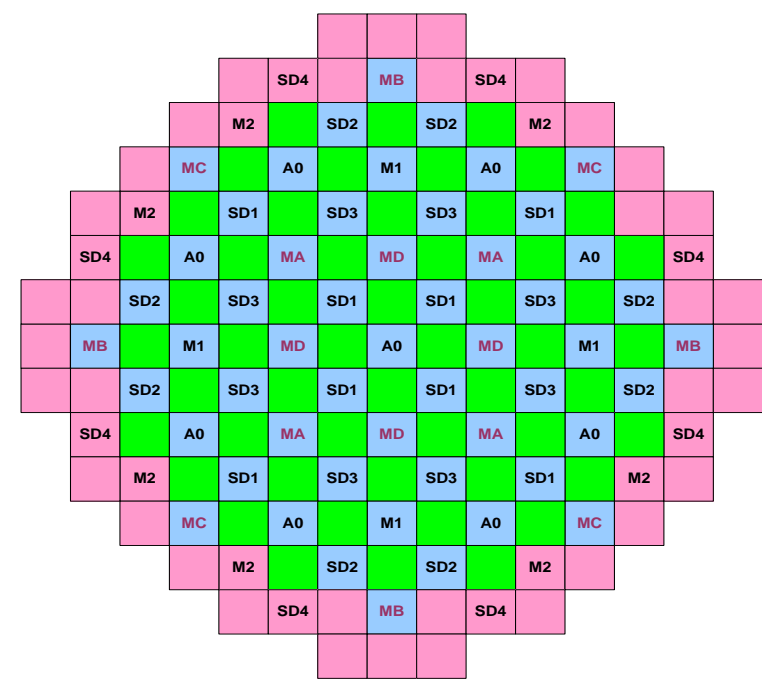

Keterangan:

MA GRCA, Bank A (shim rod), 4 buah

MB GRCA, Bank B (shim rod), 4 buah

MC GRCA, BankC (shim rod), 4 buah

MD GRCA, Bank D (shim rod), 4 buah

M1 RCCA, Bank 1 (shim rod), 4 buah

M2 RCCA, Bank 1 (shim rod), 8 buah

AO RCCA, control bank, 9 buah

SD1 RCCA, Bank 1(pemadam), 8 buah

SD2 RCCA, Bank 2(pemadam), 8 buah

SD3 RCCA, Bank 3(pemadam), 8 buah

SD4 RCCA, Bank 4(pemadam), 8 buah

Gambar 1. Data desain perangkat bahan bakar [11] 
Tabel 1. Desain reaktor PWR [12]

\begin{tabular}{|c|c|}
\hline Parameter & Nilai \\
\hline \multicolumn{2}{|l|}{ Daya reaktor: } \\
\hline Daya termal, MW & 3400 \\
\hline Daya elektrik, MW & 1117 \\
\hline Panas yang dibangkitkan di bahan bakar, $\%$ & 97,4 \\
\hline \multicolumn{2}{|l|}{ Teras aktif: } \\
\hline Tinggi bahan bakar aktif di teras pertama, cm & 426,7 \\
\hline Diameter ekivalen, $\mathrm{cm}$ & 304 \\
\hline \multicolumn{2}{|l|}{ Komposisi dan dimensi reflektor $\operatorname{air}\left(\mathrm{H}_{2} \mathrm{O}\right)$ : } \\
\hline Bagian atas (top) - air dan SS304, cm & $\sim 25,4$ \\
\hline Bagian bawah (bottom) - air dan SS304, cm & $\sim 25,4$ \\
\hline Bagian samping (side) - air dan SS304, cm & $\sim 38,1$ \\
\hline \multicolumn{2}{|l|}{ Perangkat bahan bakar: } \\
\hline Susunan 1 (satu) perangkat & $17 \times 17$ \\
\hline Jumlah perangkat dalam satu teras & 157 \\
\hline Material bahan bakar & $\mathrm{UO}_{2}($ sintered $)$ \\
\hline Pengkayaan ${ }^{235} \mathrm{U}, \mathrm{w} \%$ & 2,$5 ; 3,0$ dan 3,7 \\
\hline Jumlah batang (rod) bahan bakar & 264 \\
\hline Jumlah tabung pengarah/instrument guide thimbles & $24 / 1$ \\
\hline \multicolumn{2}{|l|}{ Batang kendali (penyerap neutron): } \\
\hline Jumlah Rod Cluster Control Assembly (RCCA) & 53 \\
\hline Jumlah Grey Rod Control Assembly (GRCA) & 16 \\
\hline \multicolumn{2}{|l|}{ Struktur teras: } \\
\hline Material core barrel & SS304 \\
\hline Diameter core barrel, ID/OD, cm & $339,72 / 349,88$ \\
\hline Material baffle & SS304 \\
\hline Ketebalan baffle, $\mathrm{cm}$ & 2,2 \\
\hline
\end{tabular}

\section{Program Komputer WIMSD-5B}

\section{Winfrith Improved Multigroup}

Scheme (WIMS) [13] banyak digunakan untuk perhitungan reaktor dengan berbagai jenis reaktor termal. WIMS terdiri dari program lattice transport code dan daftar pustaka (library) yang bersesuaian. Matriks hamburan termal yang bergantung pada suhu untuk berbagai hukum hamburan dimasukkan dalam librari untuk para pembuat kode utama yang meliputi hidrogen, deuterium, grafit, berilium, dan oksigen. Perlakuan resonansi didasarkan pada perkiraan resonansi menengah dan teorema kesetaraan. Prosedur teori tumbukan memberikan perhitungan spektrum yang akurat dalam 69 kelompok librari untuk wilayah utama kisi menggunakan representasi geometris sederhana dari sel-sel kisi. Spektra yang dihitung kemudian digunakan untuk kondensasi penampang ke jumlah kelompok yang dipilih untuk solusi persamaan transportasi dalam geometri rinci. Solusi dari persamaan transportasi disediakan baik 
dengan menggunakan metode Carlson DSN atau dengan metode kemungkinan collision. Kalkulasi kebocoran termasuk yang diperhitungkan untuk asimetri streaming B1 yang lebih rumit. Output dari perhitunagn WIMS memberikan nilai eigen untuk kasuskasus dimana mode buckling sederhana berlaku atau parameter rata-rata sel untuk digunakan dalam perhitungan reaktor keseluruhan. Berbagai setingan laju reaksi disediakan untuk perbandingan langsung dengan pengukuran eksperimental. Perlu dicatat bahwa program WIMSD-5B memiliki kemampuan lebih untuk menggunakan struktur grup energi fleksibel dibandingkan dengan pendahulunya WIMSD-4. Librari menggunakan struktur grup 69 yang terdiri dari[14]:

- 14 grup dalam rentang energi cepat ( $10 \mathrm{MeV}$ hingga 9,118 KeV).

- 13 grup dalam rentang energi resonansi $(9,118 \mathrm{KeV}$ hingga $4 \mathrm{eV})$

- 42 kelompok energi termal (di bawah $4 \mathrm{eV})$

\section{METODOLOGI}

Paket program perhitungan sel (cell atau lattice) digunakan untuk menghitung distribusi fluks neutron dan faktor perlipatan tak hingga dari sel bahan bakar. Untuk mengitungnya diperlukan masukan tampang lintang neutron beberapa nuklida, geometri sel dan menyelesaikan persamaan transpor neutron untuk seluruh daerah sel. Sel yang digunakan berupa unit sel dan paket perhitungan sel memasukkan persamaan transpor neutron untuk mendapatkan distribusi fluks neutron dan faktor perlipatan tak hingga $\left(\mathrm{k}_{\text {inf }}\right)$ dalam kelompok tenaga neutron dan fungsi ruang. Dalam studi saat ini, unit sel yang ditangani oleh WIMSD secara mendasar terdiri dari 4 daerah yaitu bahan bakar (1), kelongsong (2), pendingin (3) dan moderator (4) yang direpresentasikan dalam geometri silinder sering disebut dengan annulus. Gambar 2 mengilustrasikan pembagian daerah unit sel. Dimana $\mathrm{H}_{2} \mathrm{O}$ dihomogenisasi dengan $\mathrm{UO}_{2}$ dan kelongsong.

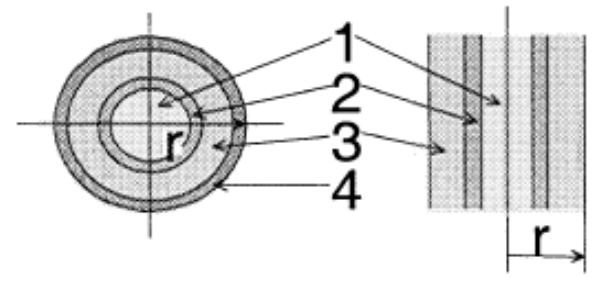

Gambar 2. Daerah dalam unit sel [16]

Setiap kasus dipilih untuk mewakili set individu. Komposisi isotop $\mathrm{U}$ ditunjukkan pada Tabel 2.

Tabel 2. Densitas atom untuk bahan bakar

\begin{tabular}{llcc}
\hline Material & $\begin{array}{c}\text { WIMS } \\
\text { ID }\end{array}$ & $\begin{array}{c}\text { Densitas } \\
\text { atom }\end{array}$ & $\begin{array}{c}\text { Temperatur } \\
(\mathrm{K})\end{array}$ \\
\hline $\mathrm{U}-234$ & 234.0 & $6,151650 \mathrm{E}-06$ & 841 \\
$\mathrm{U}-235$ & 2235.0 & $6,892200 \mathrm{E}-04$ & \\
$\mathrm{U}-236$ & 236.0 & $3,162650 \mathrm{E}-06$ & \\
$\mathrm{U}-238$ & 8238.0 & $2,171040 \mathrm{E}-02$ & \\
$\mathrm{O}$ & 6016 & $4,481780 \mathrm{E}-02$ &
\end{tabular}

Reaksi isotop ${ }^{235} \mathrm{U}$ dan ${ }^{238} \mathrm{U}$ pada temperatur $841 \mathrm{~K}$ dihitung dalam kisi benchmark 
menggunakan program WIMSD-5B.

Parameter integral yang dihitung adalah faktor multiplikasi tak terhingga (k-inf), tampang lintang makroskopik seperti koefisien difusi, tampang lintang absorpsi, tampang lintang removal, v-fisi untuk 69 kelompok energi neutron [15] yang dihitung dengan energi termal 0,625 eV. Komposisi dan radius yang mewakili sel didefenisikan dalam data material dan spektrum yang disesuaikan dengan ke-empat daerah tersebut dan hal ini sudah dilakukan oleh paket program WIMSD-5B. Jika tidak ingin materialnya dibobot oleh spektrum yang ada, maka diberi tanda negatif agar terjadi pengabaian. Hal ini terutama perlu dilakukan jika menghadapi sel berpenyerap kuat. Dengan menggunakan bentuk spektrum tersebut dilakukan perhitungan sel. Konsep ini mengindikasikan paket program WIMD memakai trik untuk mendapatkan hasil yang akurat.

Secara umum, identifikasi komposisi material pin bahan bakar terdiri dari kelongsong, bahan bakar dan air. Bahan bakar $\mathrm{UO}_{2}$ dan kelongsong adalah Zirkaloy4. Kerapatan atom dan ID WIMS-nya diimplementasikan dalam kode sebagai argumen ke kartu MATERIAL. Kerapatan atom untuk bahan bakar dicantumkan pada Tabel 2 dan kelongsong serta pendingin dalam Tabel 3.
Tabel 3. Densitas atom untuk kelongsong dan moderator

\begin{tabular}{llll}
\hline Material & $\begin{array}{c}\text { WIMS } \\
\text { ID }\end{array}$ & Densitas atom & $\begin{array}{c}\text { Temperatur } \\
(\mathrm{K})\end{array}$ \\
\hline $\mathrm{Zr}$ & 91 & $4,234250 \mathrm{E}-02$ & 620 \\
$\mathrm{Fe}$ & 2056 & $3,531875 \mathrm{E}-04$ & \\
$\mathrm{H}$ & 3001 & $5,061530 \mathrm{E}-02$ & 558 \\
$\mathrm{O}$ & 6016 & $2,530765 \mathrm{E}-02$ & \\
$\mathrm{~B}$ & 1011 & $1,394512 \mathrm{E}-05$ & \\
& & & \\
\hline
\end{tabular}

Temperatur untuk bahan bakar $814 \mathrm{~K}$ dan kelongsong diatur ke $620 \mathrm{~K}$ serta pendingin $558 \mathrm{~K}$. Perhitungan densitas atom dihitung dengan menggunakan rumus $\mathrm{N}_{\mathrm{i}}=$ $0,6022 \rho_{\mathrm{i}} / \mathrm{A}_{\mathrm{i}}$ atom $/ \mathrm{cm}^{3}$ barn. Penentuan temperatur bahan bakar, kelongsong dan air digunakan seperti temperatur reaktor PWR beroperasi normal, sehingga ketiga material tersebut dibedakan temperaturnya. Di dalam air sebagai pendingin ditambahkan boron pada kasus ini sebesar 1,394512E-05 atom/barn cm. Kelonsong bahan bakar PWR adalah zirkaloy.

\section{HASIL DAN PEMBAHASAN}

Hasil perhitungan WIMS dapat dilihat pada Gambar 3 yaitu koefisien difusi, sigma absorpsi, sigma removal dan nu-fisi. Pada grup energi neutron cepat koefisien difusi sangat tinggi sedangkan pada grup termal sangat rendah. Hal ini menyatakan bahwa energi yang dikandung neutron sangat mempengaruhi neutron berdifusi. Sigma removal berbanding terbalik dengan koefisien difusi. Sigma absorpsi dan nu-fisi pada energi tinggi nilai 
konstanta makroskopiknya kecil sedangkan pada energi termal tinggi karena jelas bahwa reaktor PWR adalah reaktor termal.

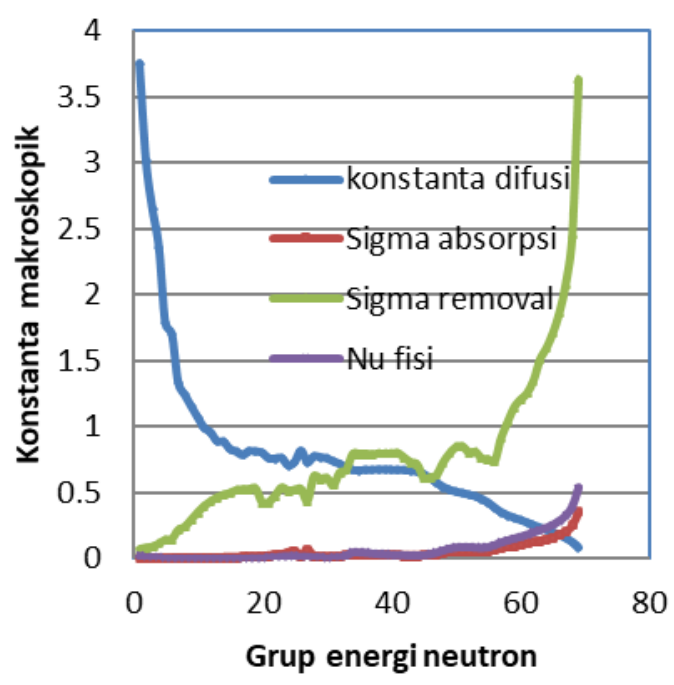

Gambar 3. Konstanta makroskopik bahan bakar PWR

Nilai k-inf hasil perhitungan WIMS dapat dilihat pada Gambar 4. Nilai k-inf awal untuk 69 dan 2 grup energi neutron adalah 1,302338 dan 1,299821. Hal ini sudah sesuai dengan kenyataannya karena faktor kebocoran neutron pada teras tidak ada.

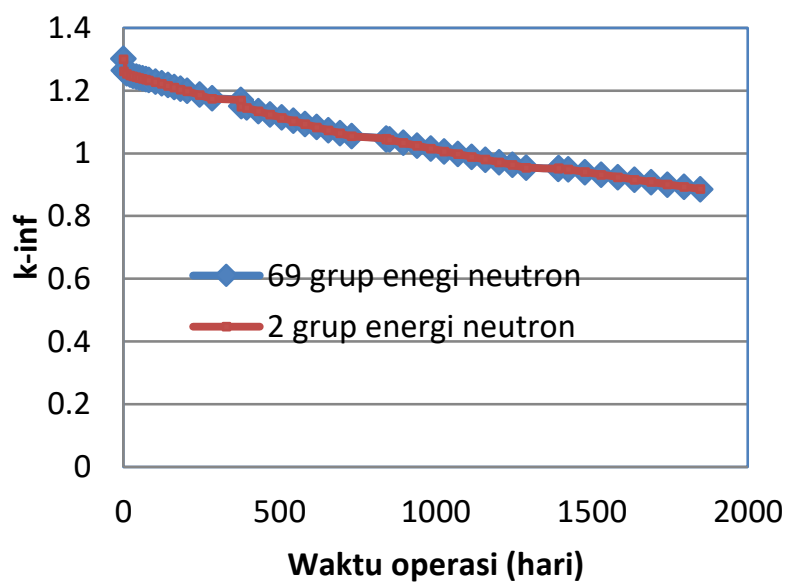

Gambar 4. Nilai k-inf fungsi waktu operasi PWR
Pada Gambar tersebut tidak terlihat perbedaan yang signifikan antara k-inf dengan 69 dan 2 grup energi neutron, sehingga dalam perhitungan parameter lain yang rumit cukup menggunakan 2 grup energi neutron, karena dengan energi grup neutron semakin banyak waktu perhitungan akan semakin lama. Nilai k-inf menurun dengan waktu operasi karena jumlah U-235 berkurang selama reaktor beroperasi. Terdapat 4 segmen nilai k-inf pada Gambar 4, karena daya pin bahan bakar yang digunakan berbeda yaitu 24,72; 26,76; 22,84 dan 18,87 MW/TU.

Nilai fraksi bakar meningkat dengan lamanya waktu operasi PWR. Nilai fraksi bahan bakar yang sering disebut dengan fuel utilization seperti yang ditunjukkan pada Gambar 5 menyatakan bahwa jumlah energi yang dihasilkan selama waktu operasi dari sumber energi bahan bakar nuklir.

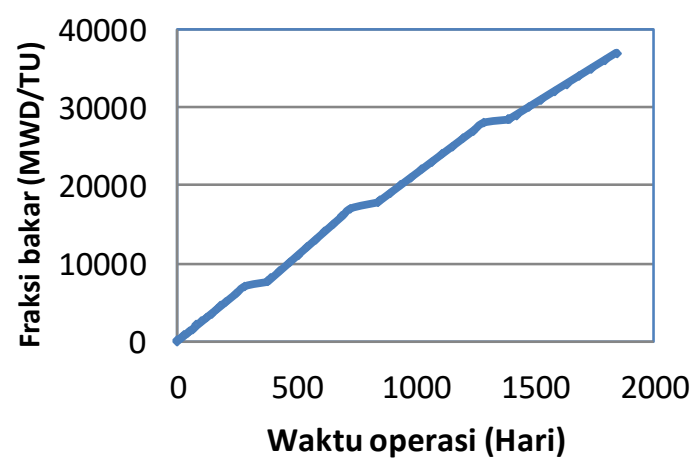

Gambar 5. Fraksi bakar fungsi waktu operasi PWR

Semakin besar jumlah energi yang dibangkitkan semakin baik dan merupakan karakteristik dari reaktor PWR. Dalam kasus 
ini dilakukan perhitungan fraksi bakar hingga 37.21 GWD/TU dengan waktu operasi sekitar 3 tahun.

Fluks neutron total hasil perhitungan WIMDS-5B dapat dilihat pada Gambar 6. Fluks neutron total merupakan gabungan dari fluks neutron cepat, neutron resonansi dan neutron termal. Fluks neutron total sangat tergantung pada daya pin bahan bakar.

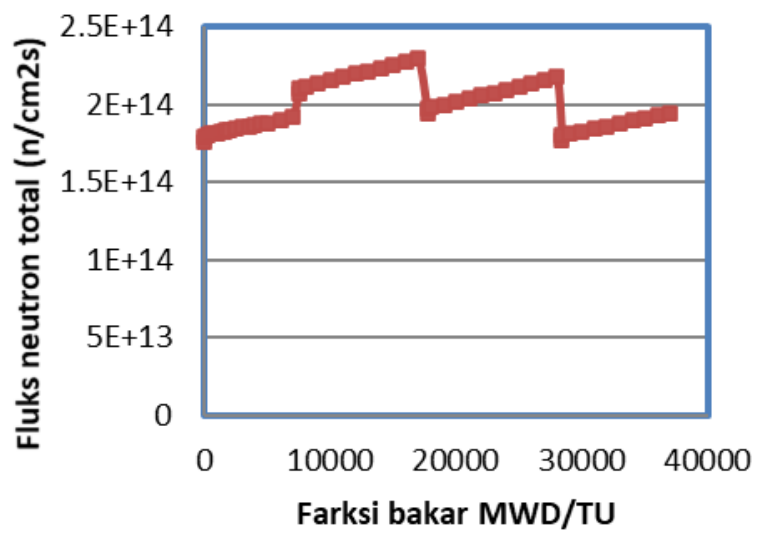

Gambar 6. Fluks neutron total fungsi fraksi bakar

Segmen pertama pada Gambar 6 menunjukkan daya pin sebesar 24,72 MW/TU dan segmen ke dua sebesar 26,76 MW/TU. Terlihat bahwa daya naik maka fluks neutron total naik. Kemudian pada segmen selanjutnya daya pin adalah sebesar 22,84 MW/TU, yang diikuti oleh fluks neutron total yang juga turun drastis. Demikian juga pada segmen ke empat, daya pin adalah sebesar 18,87 MW/TU dan fluks neutron total turun. Fluks neutron total dihasilkan dalam perhitungan ini adalah dalam orde $10^{14}$. Hasil perhitungan ini sudah sesuai dengan fluks neutron yang dihasilkan oleh A. Hamzah dkk. pada teras AP1000 [17]

Fluks neutron cepat hasil perhitungan WIMDS-5B dapat dilihat pada Gambar 7. Neutron cepat dapat diserap oleh U-238 akan berubah menjadi Pu-239 sehingga dalam kenyataannya jumlah U-238 menurun sebanding dengan lamanya waktu operasi. Fluks neutron cepat juga sangat tergantung pada daya pin bahan bakar.

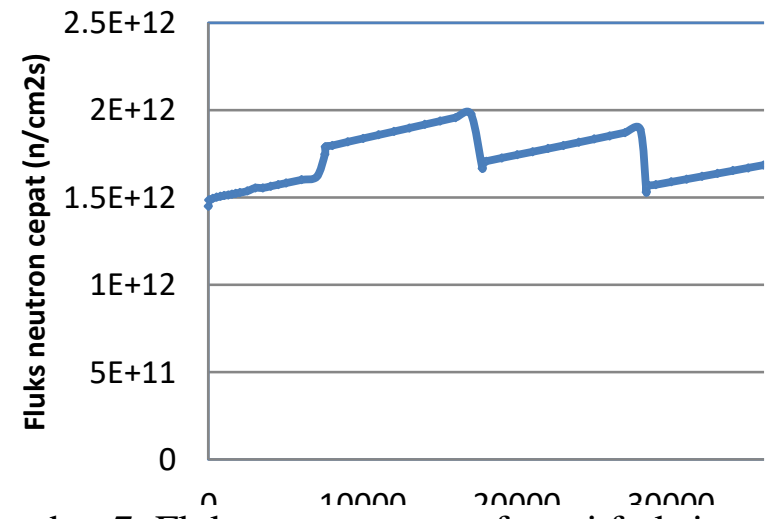

Gambar 7. Fluks neutron cepat fungsi fraksi bakar

Segmen pertama pada Gambar 7 menunjukkan daya pin sebesar 24,72 MW/TU dan segmen ke dua 26,76 MW/TU. Jelas kelihatan bahwa daya naik maka fluks neutron juga naik. Kemudian pada segmen selanjutnya daya pin 22,84 MW/TU, fluks neutron cepat juga turun drastis demikian juga pada segmen ke empat daya pin 18,87 MW/TU fluks neutron cepat turun. Fluks neutron cepat dihasilkan dalam perhitungan ini adalah dalam orde $10^{12}$.

Densitas U-235 menurun seiring dengan lamanya waktu operasi reaktor 
PWR. Pada Gambar 8 ditunjukan jumlah U235 selama reaktor dapat dioperasikan. Inti U-235 ditembak neutron termal akan berfisi menghasilkan produk fisi, energi panas dan neutron. Energi panas ini akan diubah menghasilkan energi listrik. Dalam makalah ini tidak dibahas hasil produk fisi.

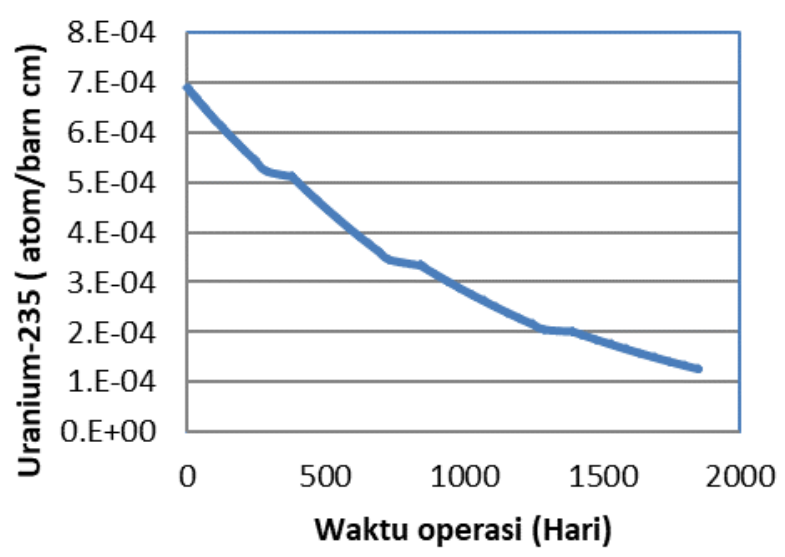

Gambar 8. Densitas atom U-235 fungsi waktu operasi PWR

Densitas U-234 juga menurun seiring dengan lamanya waktu operasi reaktor PWR. Pada Gambar 9 ditunjukkan jumlah U-234 selama reaktor dapat dioperasikan. Inti U-234 ditembak neutron termal akan diserap dan inti U-234 bertransmutasi berubah menjadi U-235 dan berfisi menghasilkan produk fisi dan energi panas serta neutron.

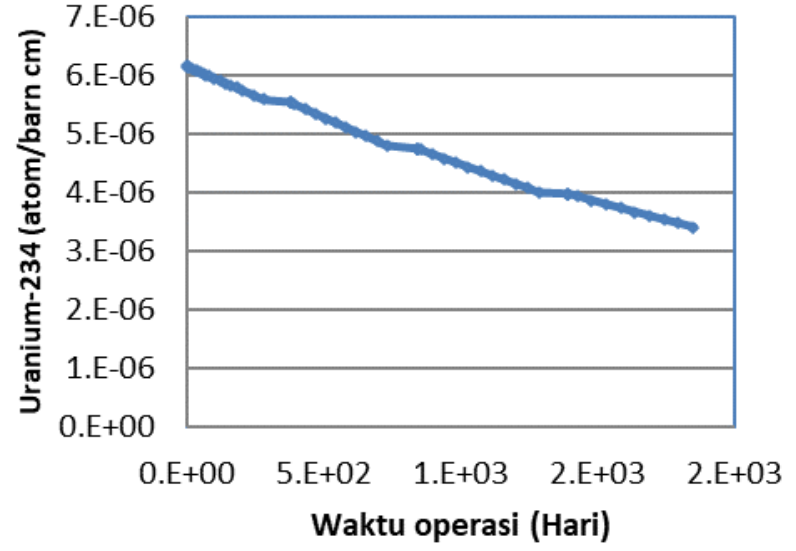

Gambar 9. Densitas atom U-234 fungsi waktu operasi PWR

Densitas U-238 juga menurun seiring dengan lamanya waktu operasi reaktor PWR. Pada Gambar 10 ditunjukan jumlah U-238 berkurang selama reaktor dapat dioperasikan. Di dalam teras reaktor, material U-238 akan menyerap neutron hasil reaksi fisi (neutron cepat) dan berubah bertransmutasi menjadi plutonium (Pu-239). Atom U-238 menyerap neutron cepat dan ada juga yang langsung berfisi. Setengah dari plutonium yang dihasilkan juga mengalami reaksi fisi dan menghasilkan sepertiga dari energi total reaktor. Untuk mempertahankan kinerja reaktor, sekitar sepertiga dari bahan bakar yang digunakan di dalam teras harus diganti dengan bahan bakar baru setiap 18 bulan. 


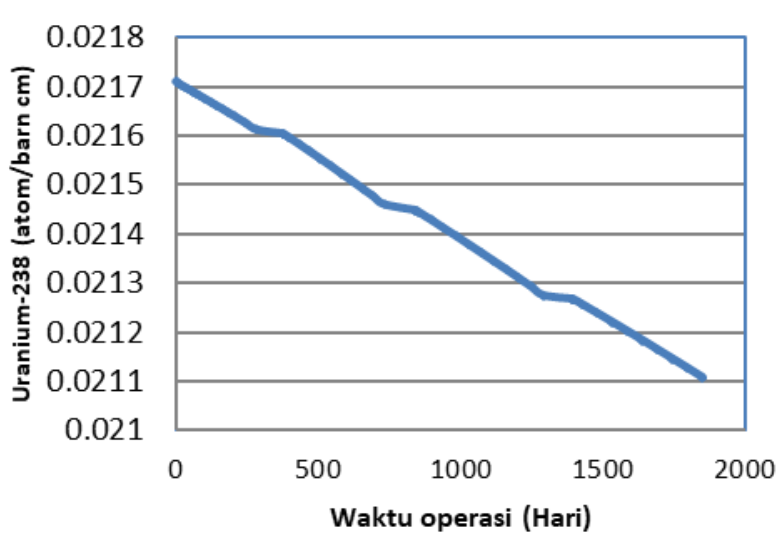

Gambar 10. Densitas atom U-238 fungsi waktu operasi PWR

Gambar 11 menunjukan densitas U-236 yang bertambah seiring dengan waktu beroperasi reaktor. U-236 diperoleh dari hasil reaksi U-235 ditembak neutron berubah intinya bertransmutasi menjadi U236.

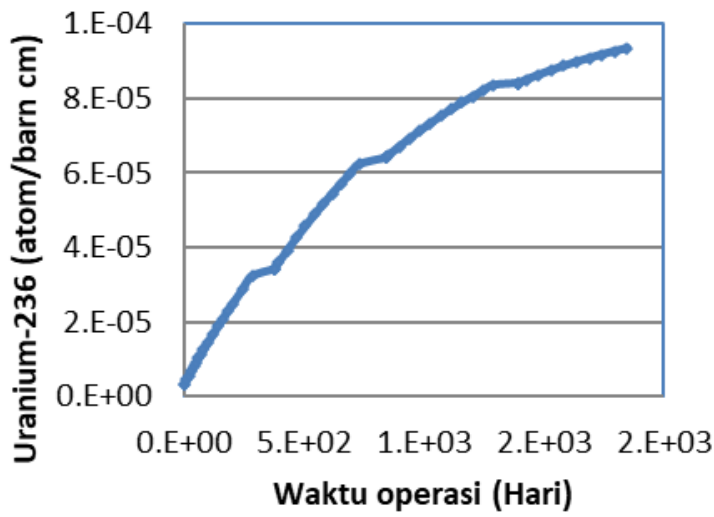

Gambar 11. Densitas atom U-236 fungsi waktu operasi PWR

Gambar 12 menunjukan jumlah densitas atom $\mathrm{Pu}$ di dalam pin bahan bakar PWR. Densitas Pu-240 jauh lebih besar dibanding $\mathrm{Pu}$ yang lain karena tampang lintang serapan U-238 jauh lebih besar dibanding Pu-239. Jauh lebih besar U-238 berubah bertansmutasi menjadi $\mathrm{Pu}-239$ dibanding dengan yang lain

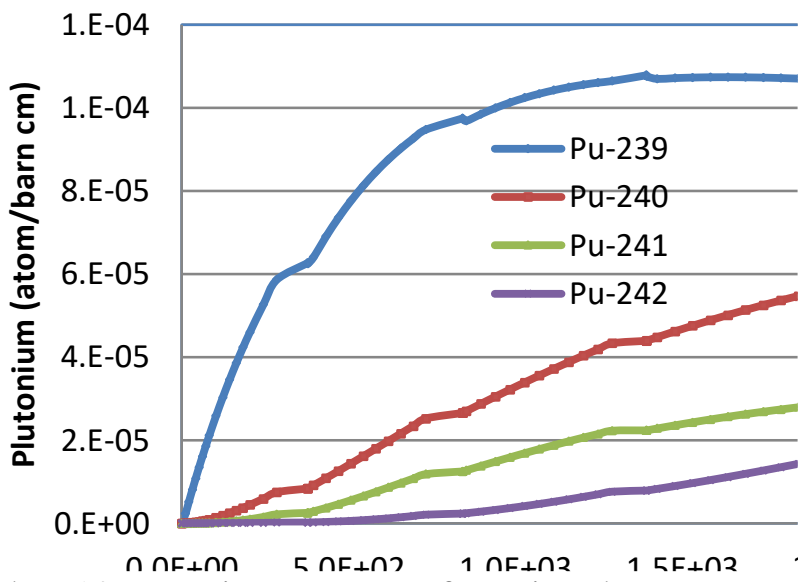

Gambar 12. Densitas atom Pu fungsi waktu operasi PWR

Gambar 13 menunjukkan hasil perhitungan spektrum neutron yang dinomalisasi terhadap satuan letarginya.

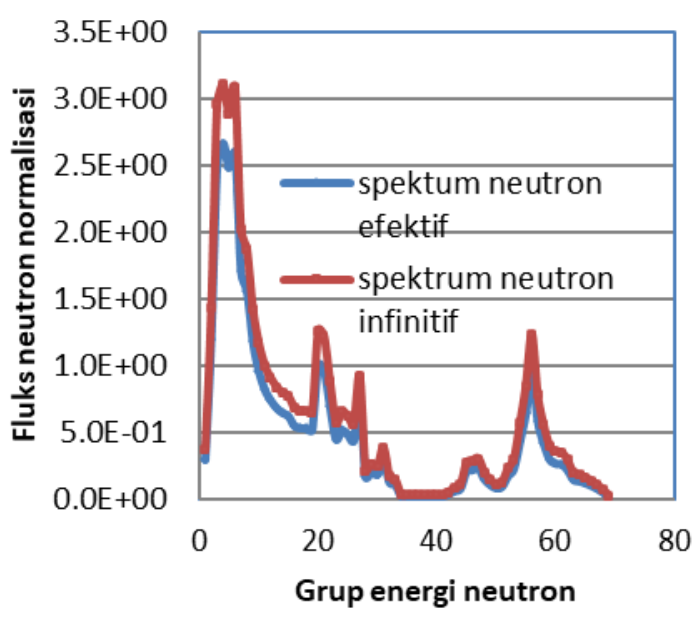

Gambar 13. Spektrum neutron fungsi energi

Spektrum neutron adalah parameter fisika reaktor yang sangat penting karena spektrum neutron digunakan untuk menentukan estimasi laju reaksi nuklir dan nilai fluks neutron. Hasil ini dapat digunakan untuk memeriksa dan memvalidasi kode fisika reaktor dengan data 
librari nuklir yang berbeda. Spektrum neutron efektif yang dihasilkan lebih kecil dari spektrum neutron infinitif karena spektrum neutron efektif mempertimbangkan kebocoran neutron dengan menggunakan parameter buckling.

\section{KESIMPULAN}

Studi parameter burnup sel bahan bakar reaktor PWR berpendingin air ringan telah dilakukan. Sel bahan bakar Uranium oksida dengan grup energi neutron 69 dan 2 tidak mempunyai perbedaan yang signifikan yaitu masing masing menghasilkan nilai $\mathrm{k}$ inf 1,302338 dan 1,299821. Nilai burnup sudah sesuai dengan kenyataan yaitu 27,12 GWD/TU dan menghasilkan pengisian bahan bakar selama 1,8 bulan. Hasil analisis distribusi fluks sangat tergantung dengan daya dan relatif sesuai dengan spektrum neutron teras PLTN PWR 1000 MWe pada daerah bahan bakar. Untuk meningkatkan ketelitian analisis, pada penelitian yang akan datang akan ditingkatkan model dan dibandingkan dengan perhitungan MCNP lebih efisien karena waktu eksekusi program masih cukup lama.

\section{UCAPAN TERIMAKASIH}

Penulis mengucapkan terimakasih kepada kepala Pusat PTKRN yang telah memberikan kesempatan untuk melakukan penelitian tugas akhir di PTKRN.

\section{DAFTAR PUSTAKA}

[1]. SURBAKTI T., PINEM S., SEMBIRING T. M. Analisis pengaruh densitas bahan bakar silisida terhadap parameter kinetik teras reaktor RSGGAS. Jurnal Penelitian Fisika dan Aplikasinya. 2013. 3(1): 19-30.

[2]. SEMBIRING T. M., SURBAKTI T., PINEM S. Neutronic design of mixed oxide-silicide cores for the core conversion of RSG-GAS reactor. Atom Indonesia. 2001. 27(2): 851001.

[3]. PINEM S, LIEM P. H., SEMBIRING T. M., SURBAKTI T. Fuel element burn-up measurements for the equilibrium LEU silicide RSG GAS (MPR-30) core under a new fuel management strategy. Ann. Nucl. Energy. 2016. 98: 211 - 217.

[4]. LIEM P. H. Validation of BATAN'S Standard 3-D diffusion code, BATAN3DIFF, on the first core of RSG GAS. Atom Indonesia. 1999. 25(1): 47-53.

[5]. LIEM P. H., TARYO T., SEMBIRING T. M., HIROSHI S., YOSHITAKA N. Study on the control rod interaction effect in RSG gas multipurpose reactor (MPR-30). Ann. Nucl. Energy. 2002. 29(6): 701-716.

[6]. SEMBIRING T. M. Penggunaan paket program WIMSD/5B.12 dan BATAN- 
2DIFF untuk RSG-GAS, Pusat Reaktor Serba Guna, April, 2011.

[7]. PINEM S., SURBAKTI T. Analysis on neutronic parameters of the AP1000 Reactor Core. in: Prosiding Seminar Nasional Teknologi Energi Nuklir, Batam. 2016, pp. 569-75.

[8]. PINEM S., SEMBIRING T. M., SURBAKTI T. PWR fuel macroscopic cross section analysis for calculation core fuel management benchmark. in: Journal of Physics: Conference Series 1198 (2), 022065

[9]. SURBAKTI T., PINEM S., SEMBIRING T. M., SUPARLINA L., SUSILO J. Desain konseptual teras reaktor riset inovatif berbahan bakar uranium-molibdenum dari aspek neutronik. Tri Dasa Mega. 2012. 3(14): 178-191.

[10]. SEMBIRING T. M., LIEM P. H., SURBAKTI T. Fuel management strategy for the compact core design of RSG GAS (MPR-30). in: RRFM 2000: research reactor fuel management, Colmar. 2000, 158-162.

[11]. LIEM P. H., SURBAKTI T., HARTANTO D. Kinetics parameters evaluation on the first core of the RSG GAS (MPR-30) using continuous energy Monte Carlo method. Progress in Nuclear Energy. 2018. 109: 196203.
[12]. SURBAKTI T., PURWADI P. Karakteristik reaktivitas teras kerja RSG-GAS selama 30 tahun beroperasi. Jurnal Penelitian Fisika dan Aplikasinya (JPFA). 2017. 7(1): 13-26.

[13]. SURBAKTI T., IMRON M. Fuel burn-up calculation for working core of the RSG-GAS research reactor at BATAN Serpong. Jurnal Penelitian Fisika dan Aplikasinya (JPFA). 2017. 7(2): 89-101.

[14]. SURBAKTI T., PINEM S., SEMBIRING T. M., HAMZAH A., NABESHIMA K. Calculation of control rods reactivity worth of RSGGAS first core using deterministic and Monte Carlo methods. Atom Indonesia. 2019. 45(2): 69-79.

[15]. SURBAKTI T., PURWADI P. Analysis of neutronic safety parameters of the Multi-Purpose Reactor-Gerrit Augustinus Siwabessy (RSG-GAS) research reactor at Serpong. Jurnal Penelitian Fisika dan Aplikasinya (JPFA). 2019. 9(1), 7891.

[16]. SURBAKTI T., SEMBIRING T. M. Analisis neutronik teras RSG-GAS berbahan bakar silisida. Indonesian Journal of Physics. 2001. 12(3), 61-67

[17]. HAMZAH A. Analisis distribusi fluks dan spektrum neutron reaktor PLTN PWR 1000 MWe menggunakan 
program MCNP. in: Prosiding

Seminar Nasional ke-18 Teknologi dan

Keselamatan PLTN Serta Fasilitas

Nuklir, Bandung. 2012. 